\title{
Nephroprotective and antioxidative effects of royal jelly on ethylene glycol induced nephropathy in rats
}

\author{
Laçine AKSOY, Zeyneb ASLAN
}

Afyon Kocatepe University, Faculty of Science and Arts, Department of Chemistry, Afyonkarahisar, Turkey.

\begin{abstract}
Summary: Antioxidative and nephroprotective effects of royal jelly against ethylene glycol induced renal injury were examined in this study. Five groups of rats were used. Rats in Group 1 served as control. Rats in Group 2 received ethylene glycol (1\%) in drinking water, while those in Group 3 received $100 \mathrm{mg} / \mathrm{kg}$ of royal jelly through oral gavage. Group 4 served as protective group and received ethylene glycol $1 \%$ in drinking water and $100 \mathrm{mg} / \mathrm{kg}$ of royal jelly administered. Group 5 served as treatment group and received ethylene glycol $1 \%$ in the drinking water for the initial 15 days, followed by $100 \mathrm{mg} / \mathrm{kg}$ of royal jelly administered last 15 days. Oxidative stress was induced by ethylene glycol. Royal jelly was found to reduce renal damage with measured BUN and CREA (creatinine) levels. It was considered that royal jelly has positive effects on antioxidant system and decreased effects on lipid peroxidation. Royal jelly may have positive nephroprotective effects on the injury induced by ethylene glycol exposure. Particularly, the effects observed in the treatment group were remarkable.

Keywords: Antioxidant, calcium oxalate, ethylene glycol, nephropathy, royal jelly.
\end{abstract}

\section{Ratlarda etilen glikolün indüklediği nefropatide arı sütünün nefroprotektif ve antioksidatif etkileri}

Özet: Bu çalışmada ratlarda etilen glikolün oluşturduğu renal hasara karşı arı sütünün antioksidatif etkileri incelendi. Ratlardan 5 çalışma grubu oluşturuldu. 1. grup kontrol grubu olarak belirlendi. 2. gruptaki ratlara etilen glikol, içme suyunda (\%1 oranında) verildi. 3. gruptaki ratlara her gün oral gavajla $100 \mathrm{mg} / \mathrm{kg}$ arı sütü verildi. 4 . grup koruyucu grup olarak belirlendi ve 30 gün boyunca içme suyunda etilen glikol (\%1) verilirken, oral gavajla $100 \mathrm{mg} / \mathrm{kg}$ arı sütü verildi. 5. grup tedavi edici grup olarak belirlendi ve çalışmanın ilk 15 günü etilen glikol (\%1) içme suyunda, son 15 gün $100 \mathrm{mg} / \mathrm{kg}$ arı sütü oral gavajla verildi. Etilen glikolün oksidatif stresi indüklediği görülmüştür. Ölçülen BUN ve CREA (kreatinin) düzeylerinden arı sütünün böbrek hasarını azalttığı bulundu. Arı sütünün antioksidatif sistemi desteklediği, lipid peroksidasyonunu azaltıcı etki gösterdiği düşünülmektedir. Etilen glikol maruziyetiyle oluşturulan hasara karşı arı sütünün olumlu etkileri olduğu söylenebilir. Arı sütü uygulamasıyla tedavi edici grupta elde edilen sonuçlar özellikle dikkat çekicidir.

Anahtar sözcükler: Antioksidan, arı sütü, etilen glikol, kalsiyum okzalat, nefropati.

\section{Introduction}

Natural substances are commonly used for medicinal purposes. Royal jelly is secreted by the hypopharyngeal region located in the head of worker bees is such example. It was originally described by Huber, who used the term "Gelee Royale" for this natural secretion (24). Earlier descriptions for this natural substance involved the use of other terms such as "Gelatine Reale", meaning "the gel for the kings", which subsequently evolved into its current form, i.e. "Royal Jelly" (21), which is also used in scientific nomenclature today. Royal jelly is secreted by the hypopharyngeal and mandibular secretory glands of the adult worker bees; these glands are also referred to as the "food glands" due to their use in the feeding of 5 to 15 day-old worker bees (26). It is immediately consumed and cannot be stored due to its propensity for quick structural changes and continuous production in the beehive (7) royal jelly consists of proteins (12-15\%), water (60-70\%), sugars (10-12\%), lipids (3-7\%), minerals, and vitamins, in addition to certain enzymes such as $\alpha$-glucosidase, glucose oxidase, catalase, and amylase (32). In bee larvae consuming royal jelly (RJ), DNA methylation occurs and gene morphology is affected RJ has been shown to have hypotensive, antitumor, antiinflammatory, antifatigue, and antiallergic effects (37).

Free radicals are atoms or molecules, which are highly reactive intermediate species that are generated through the cleavage of covalent bonds and that carry a single unpaired electron. Free radicals are natural consequences of metabolic functions of an organism. They play timely roles in the process of apoptosis and cellular life-span. Most are generated as byproducts of chemical reactions, which are vital for life. Effects of free radicals are balanced by antioxidant agents. Disturbance of this balance in favor of free radicals results in oxidative stress, leading to detrimental effects on proteins, DNA, 
carbohydrates, and lipid biomolecules. In tissues and cells, a system exists that scavenges these radical products and suppresses these radical reactions. Substances that prevent progression of peroxidation by quickly and effectively reacting with these radicals are referred to as "antioxidants". The antioxidant system is responsible for prevention of the attack of free radicals on macromolecules and cellular structures $(17,34)$.

Urolithiasis is a medical condition that has been affecting humans for centuries. Risk factors in the development of urolithiasis include age, gender, family history, nutritional habits, geographical and climate conditions. Stones of the urinary system are categorized as organic and inorganic and approximately $70 \%$ of all stones consist of calcium oxalate. Main target in medical management of urinary stones is to correct abnormalities in the composition of urine, removal of the risk factors, and prevention of recurrence. Interventions in urolithiasis include prophylactic measures and chemolysis. Chemolysis is the dissolving and removal of stones using certain agents. Prophylactic measures aim at reducing supersaturation, to alleviate inhibitor deficiency, and remove promoters. However, these approaches involve certain challenges in certain situations such as pregnancy, untreated urinary system infections, active tuberculosis, stenosis at some points in the urinary system, obesity, short stature, or skeletal abnormalities $(16,27)$. In this study, antioxidative effects of royal jelly against renal tubular injury induced by ethylene glycol was examined.

\section{Materials and Methods}

Chemicals and experimental protocol: Urolithiasis was induced by ethylene glycol provided by Merck (Darmstadt, Germany). Royal jelly was directly provided by a natural honey producer in Turkey (Nurhak, Kahramanmaraş, Turkey). Before the study procedures, study protocol was approved by the Animal Ethics Committee of Afyon Kocatepe University (approval date and no: 26/09/2013, AKÜHADYEK-284-13). A total of 35 male Sprague-Dawley rats weighing between 300 and 380 grams were used in the study. All rats were kept under ideal 12-h cycles of light and temperature conditions and were fed with standard pellet (Bilyem, Ankara, Turkey).

Group 1 (Control group, $n=7$ ) received standard food and tap water. Group 2 (EG group, $n=7$ ) received standard food and drinking water, in which $1 \%$ ethylene glycol was added during study period. Group 3 (RJ group, $n=7$ ) received $100 \mathrm{mg} / \mathrm{kg}$ royal jelly through oral gavage. Group 4: $(\mathrm{RJ}+\mathrm{EG}$ group, $\mathrm{n}=7)$ received $1 \%$ ethylene glycol in drinking water, in addition to $100 \mathrm{mg} / \mathrm{kg}$ royal jelly administered with oral gavage. Group 5 (EG + RJ group, $\mathrm{n}=7$ ) received $1 \%$ ethylene glycol in drinking water for the first 15 -day period, followed by $100 \mathrm{mg} / \mathrm{kg}$ of royal jelly administered by oral gavage in the second 15-day period of the study.
Biochemical analyses in plasma, erythrocytes and tissues: Plasma creatinine (CREA) and blood urea nitrogen (BUN) levels were measured by an autoanalyzer (Cobas 6000; Roche, Switzerland) as indicators of renal failure.

Erythrocyte malondialdehyde (MDA) levels were measured according to the method that is based on the reaction between MDA and thiobarbituric acid (TBA) resulting in the formation of a colored complex. The absorbance measurements in the complex provide indication for the degree of lipid peroxidation Jain et al. (22). Tissue MDA levels were determined according Ohkawa et al.'s (31) method.

NO measurements in plasma samples and tissue homogenates were performed according to Miranda et al. (29). In this method, nitrate is converted into nitrite by Vanadium (III) chloride $\left(\mathrm{VCl}_{3}\right)$. Absorbance of the complex formed by reaction of nitrite and sulphanylamide with N-(1-Naphtyl) ethylenediamine dihidrochloride (NEDD) in an acidic environment was measured.

Total oxidative status in plasma samples and tissue homogenates were determined using commercial kits (Rel Assy, Lot: RL034). Substances with oxidative capacity in samples result in oxidation of $\mathrm{Fe}^{2+}$ to $\mathrm{Fe}^{3+}$. The complex formed by $\mathrm{Fe}^{3+}$ and xylenol orange in an acidic environment is proportional to the amount of oxidative substances in a sample (15). The oxidative stress index (OSI) is expressed as the proportion between total oxidative status to total antioxidant status. OSI was calculated by multiplying TAS by 100, equilizing TOS and the units (15).

GSH concentrations in erythrocyte samples and tissue homogenates were measured on the basis of reduction of 5,5'-dithiobis-(2-nitrobenzoic acid) (DTNB) by GSH, as described by Beutler et al. (5). In this method, precipitation of proteins with a sulfhydryl (-SH) moiety is accomplished and GSH concentration is estimated by addition of DTNB.

Catalase levels (CAT) were determined in erythrocytes and tissue homogenates using Aebi's method (1). CAT is the enzyme responsible for the breakdown of $\mathrm{H}_{2} \mathrm{O}_{2}$ into water and oxygen and during the measurement of CAT activity, $\mathrm{H}_{2} \mathrm{O}_{2}$ was used as a substrate.

Total antioxidant levels of plasma samples and tissue homogenates were determined using commercial kits (Rel Assay, Lot: RL031). In this method, reduction of cation radical by the colored 2,2'-azino-bis (3-ethylbenzothiazolin6-sulphonic acid) (ABTS) results in decolorization of this radical that is proportional to the concentration of total antioxidants (14).

Total protein concentration was measured in tissue homogenates using commercial kits (6). The resultant total protein concentration was used in the estimation of the parameters analyzed within the renal and hepatic tissues. All biochemical measurements were performed by ELISA (Biotek ELx800). 
Collection and analysis of urine: On 0,15 and $30^{\text {th }}$ days of the study, rats were kept in metabolic cages for 24 hours, during which urinary $\mathrm{Ca}^{2+}, \mathrm{PO}_{4}{ }^{3-}$ and $\mathrm{pH}$ were determined.

Statistical analysis: Data were expressed as mean \pm standard deviation (SD). Statistical comparisons were performed using appropriate ANOVA model with Duncan post-hoc tests. Differences with $\mathrm{p}<0.05$ were considered significant. SPSS 15.0 package for Windows was used for statistical analysis.

\section{Results}

In this study, antioxidant effects of royal jelly on renal injury and oxidative stress induced by ethylene glycol were examined. At the final stage of the study CREA, BUN, MDA, NO, TOS, OSI, GSH, CAT, TAS,
$\mathrm{Ca}^{2+}, \mathrm{PO}_{4}{ }^{3-}$ and $\mathrm{pH}$ assays were performed in blood, tissue and urine samples obtained from rats. Using the data, a statistical analysis was done.

Plasma CREA and BUN levels: Plasma CREA and BUN levels were measured to determine nephropathy (Table 1). The EG group CREA and BUN levels were higher than control group $(\mathrm{p}<0.05)$. EG group had a decrease in CREA and BUN levels compared to RJ+ EG group $(\mathrm{p}<0.05)$.

Erythrocyte and kidney tissue MDA levels: MDA levels in erythrocytes and kidney samples were measured. As depicted in Table 2, a significantly higher erythrocyte MDA level was found in EG group as compared to control and RJ groups $(\mathrm{p}<0.05)$. Similarly, a significantly higher MDA value was detected in EG group in comparison to control and RJ groups $(\mathrm{p}<0.05)$.

Table 1. Plasma creatinine and BUN levels.

Tablo1. Plazma kreatinin ve BUN düzeyleri.

\begin{tabular}{llllll}
\hline Group & Control & EG & RJ & RJ+EG & EG+RJ \\
\hline Creatinine (mg/dL) & $0.39 \pm 0.03^{\mathrm{a}}$ & $0.54 \pm 0.07^{\mathrm{b}}$ & $0.38 \pm 0.02^{\mathrm{a}}$ & $0.44 \pm 0.16^{\mathrm{c}}$ & $0.43 \pm 0.08^{\mathrm{c}}$ \\
BUN (mg/dL) & $22.62 \pm 4.3^{\mathrm{b}}$ & $39.75 \pm 3.67^{\mathrm{a}}$ & $25.91 \pm 2.78^{\mathrm{b}}$ & $30.06 \pm 1.84^{\mathrm{c}}$ & $34.25 \pm 2.66^{\mathrm{ac}}$ \\
\hline
\end{tabular}

a,b,c: Differences between the groups that are coded with different letters in the same line are significant ( $\mathrm{p}<0.05)$. EG represents the group administered with ethylene glycol; RJ represents the group solely administered with Royal Jelly; RJ+EG represents the group simultaneously administered with Royal Jelly and ethylene glycol; EG+RJ represents the group administered with Royal Jelly after renal injury with ethylene glycol.

a, b, c: Aynı satırda başka harflerle gösterilen farklılıklar anlamlıdır ( $<<0.05)$. EG, etilen glikolun uygulandığı grubu gösterir; RJ, yalnız arı sütü uygulanan grubu gösterir; RJ+EG,arı sütü ile birlikte etilen glikol uygulanan grubu gösterir; EG+RJ, etilen glikolle renal hasar oluşumundan sonra arı sütünün uygulandığı grubu gösterir.

Table 2. Erythrocyte, plasma and kidney tissue oxidative stress marker levels.

Tablo 2. Eritrosit, plazma ve böbrek doku oksidatif stress düzeyleri.

\begin{tabular}{|c|c|c|c|c|c|}
\hline Group & Control & EG & $\mathrm{RJ}$ & $\mathrm{RJ}+\mathrm{EG}$ & $\mathrm{EG}+\mathrm{RJ}$ \\
\hline $\begin{array}{l}\text { Erythrocytes MDA } \\
\mathrm{nmol} / \mathrm{gHb}\end{array}$ & $1.66 \pm 0.04^{\mathrm{b}}$ & $2.35 \pm 0.19^{\mathrm{a}}$ & $1.97 \pm 0.10^{\mathrm{c}}$ & $2.09 \pm 0.15^{\mathrm{c}}$ & $2.04 \pm 0.16^{\mathrm{c}}$ \\
\hline $\begin{array}{l}\text { Kidney MDA } \\
\mathrm{nmol} / \mathrm{g} \text { protein }\end{array}$ & $6.92 \pm 0.20^{\mathrm{b}}$ & $8.88 \pm 0.37^{\mathrm{a}}$ & $7.75 \pm 0.42^{\mathrm{c}}$ & $7.97 \pm 0.43^{c}$ & $8.04 \pm 0.32^{\mathrm{c}}$ \\
\hline $\begin{array}{l}\text { Plasma NO } \\
\mu \mathrm{mol} / \mathrm{L}(\mathrm{NO})_{\chi}\end{array}$ & $75.20 \pm 4.47^{\mathrm{ab}}$ & $82.01 \pm 2.68^{\mathrm{a}}$ & $69.99 \pm 6.36^{\mathrm{b}}$ & $76.80 \pm 6.84^{\mathrm{ab}}$ & $71.41 \pm 7.89^{b}$ \\
\hline $\begin{array}{l}\text { Kidney NO } \\
\mu \mathrm{mol}(\mathrm{NO})_{\chi} / \mathrm{mg} \text { protein }\end{array}$ & $20.08 \pm 1.85^{\mathrm{ad}}$ & $17.35 \pm 1.26^{\mathrm{c}}$ & $18.12 \pm 1.94^{\mathrm{cd}}$ & $12.68 \pm 1.36^{\mathrm{b}}$ & $21.95 \pm 2.36^{\mathrm{a}}$ \\
\hline $\begin{array}{l}\text { Plasma TOS } \\
\mu \mathrm{mol} \mathrm{H}_{2} \mathrm{O}_{2} \text { Equiv./L }\end{array}$ & $5.20 \pm 0.70^{\mathrm{b}}$ & $10.40 \pm 0.77^{\mathrm{a}}$ & $7.30 \pm 0.92^{c}$ & $6.03 \pm 0.71^{b}$ & $5.87 \pm 0.19^{b}$ \\
\hline $\begin{array}{l}\text { Kidney TOS } \\
\text { mmol TroloxEquiv./mg protein }\end{array}$ & $7.26 \pm 0.42^{\mathrm{c}}$ & $16.34 \pm 0.82^{\mathrm{a}}$ & $6.37 \pm 0.99^{b}$ & $8.08 \pm 0.59^{c}$ & $7.50 \pm 0.50^{c}$ \\
\hline $\begin{array}{l}\text { Plasma OSİ } \\
\text { Arbitury Unit }\end{array}$ & $360.87 \pm 50.58^{b}$ & $2170.88 \pm 351.44^{\mathrm{a}}$ & $660.15 \pm 72.54^{\mathrm{c}}$ & $801.37 \pm 42.96^{c}$ & $665.76 \pm 1.75^{\mathrm{c}}$ \\
\hline $\begin{array}{l}\text { Kidney OSİ } \\
\text { Arbitury Unit }\end{array}$ & $931.04 \pm 92.56^{\mathrm{bc}}$ & $5317.02 \pm 705.23^{\mathrm{a}}$ & $766.52 \pm 56.75^{b}$ & $1292.38 \pm 153.83^{c}$ & $1312.39 \pm 200.36^{c}$ \\
\hline
\end{tabular}

a, b, c, d: Differences between the groups that are coded with different letters in the same column are significant $(\mathrm{p}<0.05)$. EG represents the group administered with ethylene glycol; RJ represents the group solely administered with royal jelly; RJ+EG represents the group simultaneously administered with Royal Jelly and ethylene glycol; EG+RJ represents the group administered with Royal Jelly after renal injury with ethylene glycol.

a, b, c, d: Aynı satırda başka harflerle gösterilen farklılıklar anlamlıdır $(\mathrm{p}<0.05)$. EG, etilen glikolun uygulandı ğı grubu gösterir; RJ, yalnız arı sütü uygulanan grubu gösterir; RJ+EG, arı sütü ile birlikte etilen glikol uygulanan grubu gösterir; EG+RJ, etilen glikolle renal hasar oluşumundan sonra arı sütünün uygulandığı grubu gösterir. 
Table 3. Erythrocyte, plasma and kidney tissue antioxidant levels.

Tablo 3. Eritrosit, plazma ve böbrek doku antioksidan düzeyleri.

\begin{tabular}{|c|c|c|c|c|c|}
\hline Group & Control & EG & RJ & $\mathrm{RJ}+\mathrm{EG}$ & $\mathrm{EG}+\mathrm{RJ}$ \\
\hline $\begin{array}{l}\text { Erythrocytes GSH } \\
\mathrm{nmol} / \mathrm{gHb}\end{array}$ & $76.42 \pm 2.98^{a}$ & $66.11 \pm 4.89^{\mathrm{b}}$ & $72.40 \pm 4.42^{\mathrm{a}}$ & $65.69 \pm 1.91^{b}$ & $62.42 \pm 5.61^{b}$ \\
\hline $\begin{array}{l}\text { Kidney GSH } \\
\mu \mathrm{mol} / \mathrm{g} \text { protein }\end{array}$ & $60.18 \pm 3.60^{a}$ & $47.91 \pm 4.33^{\mathrm{b}}$ & $63.05 \pm 3.80^{\mathrm{a}}$ & $46.11 \pm 3.26^{b}$ & $43.85 \pm 3.48^{b}$ \\
\hline $\begin{array}{l}\text { Erythrocytes CAT } \\
\text { k/g Hb }\end{array}$ & $3.42 \pm 0.47^{\mathrm{a}}$ & $1.98 \pm 0.22^{\mathrm{b}}$ & $3.36 \pm 0.36^{\mathrm{a}}$ & $2.39 \pm 0.32^{b c}$ & $2.61 \pm 0.36^{\mathrm{c}}$ \\
\hline $\begin{array}{l}\text { Kidney CAT } \\
\text { k/g protein }\end{array}$ & $1.89 \pm 0.17^{\mathrm{a}}$ & $1.26 \pm 0.05^{\mathrm{b}}$ & $1.72 \pm 0.08^{c}$ & $1.79 \pm 0.12^{\mathrm{ac}}$ & $1.79 \pm 0.10^{\mathrm{ac}}$ \\
\hline $\begin{array}{l}\text { Plasma TAS } \\
\mu \text { mol TroloxEquiv./L }\end{array}$ & $1.44 \pm 0.06^{\mathrm{a}}$ & $0.49 \pm 0.06^{\mathrm{b}}$ & $1.11 \pm 0.07^{\mathrm{e}}$ & $0.76 \pm 0.06^{\mathrm{c}}$ & $0.89 \pm 0.07^{\mathrm{d}}$ \\
\hline $\begin{array}{l}\text { Kidney TAS } \\
\text { mmol TroloxEquiv./mg protein }\end{array}$ & $0.78 \pm 0.07^{\mathrm{a}}$ & $0.31 \pm 0.04^{\mathrm{b}}$ & $0.83 \pm 0.09^{\mathrm{a}}$ & $0.63 \pm 0.06^{\mathrm{c}}$ & $0.58 \pm 0.06^{\mathrm{c}}$ \\
\hline
\end{tabular}

$\mathrm{a}, \mathrm{b}, \mathrm{c}, \mathrm{d}$, e: Differences between the groups that are coded with different letters in the same column are significant $(\mathrm{p}<0.05)$. EG represents the group administered with ethylene glycol; Royal Jelly represents the group solely administered with Royal Jelly; RJ+EG represents the group simultaneously administered with Royal Jelly and ethylene glycol; EG+RJ represents the group administered with Royal Jelly after renal injury with ethylene glycol.

a, b, c, d, e: Aynı satırda başka harflerle gösterilen farklılıklar anlamlıdır ( $<<0.05)$. EG, etilen glikolun uygulandığı grubu gösterir; RJ, yalnız arı sütü uygulanan grubu gösterir; RJ+EG, arı sütü ile birlikte etilen glikol uygulanan grubu gösterir; EG+RJ, etilen glikolle renal hasar oluşumundan sonra arı sütünün uygulandığı grubu gösterir.

Plasma and kidney tissue NO levels: Plasma and kidney NO levels were determined. As shown in Table 2 for plasma measurements, there were no significant differences between control and other groups ( $p>0.05)$. $\mathrm{NO}$ values in RJ and EG + RJ groups were significantly $(p<0.05)$ lower as compared to NO in EG group. With regard to renal NO levels, a statistically significant difference between control and EG groups was observed $(\mathrm{p}<0.05)$. NO in EG group was also significantly different from that in $\mathrm{EG}+\mathrm{RJ}$ and $\mathrm{RJ}+\mathrm{EG}$ groups $(\mathrm{p}<0.05)$.

Plasma and kidney tissue TOS assay: TOS were measured in plasma and kidney samples. According to plasma TOS results as depicted in Table 2, significantly higher TOS was found in EG group than in other groups $(p<0.05)$. TOS in royal jelly group was significantly higher as compared to controls, EG + RJ, and RJ + EG, while it was significantly lower as compared to EG group ( $p<0.05$, both). Kidney TOS values were very similar to those observed for plasma TOS. TOS in control group did not differ significantly from that in EG + RJ and RJ + EG groups $(p>0.05)$. TOS in EG group was significantly higher than all other groups $(\mathrm{p}<0.05)$. TOS in RJ group was significantly higher than in control, EG + RJ and RJ $+\mathrm{EG}$, while significantly lower as compared to EG group $(\mathrm{p}<0.05)$.

Plasma and kidney tissue OSI assay: As shown in Table 2, with regard to plasma OSI, control group did not differ significantly from other groups $(\mathrm{p}<0.05)$, while OSI in EG group was significantly higher than other groups $(\mathrm{p}<0.05)$. RJ, EG + RJ, and RJ + EG groups had significantly higher OSI than control and significantly lower OSI than EG group ( $p<0.05$, both). In terms of renal
OSI, RJ group had significantly lower OSI than EG + RJ and RJ + EG groups $(p<0.05)$. On the other hand, EG group had significantly higher OSI as compared to other groups $(\mathrm{p}<0.05)$.

Erythrocyte and kidney tissue GSH levels: GSH levels in erythrocytes and kidney samples were measured. As can be seen in Table 3, with regard to erythrocyte GSH control and RJ groups did not differ significantly ( $p>0.05)$, while there was a significant difference between control group and EG, RJ + EG, and EG + RJ groups ( $\mathrm{p}<0.05)$. GSH in EG group showed a significant reduction $(\mathrm{p}<0.05)$ as compared to control. GSH level in RJ group was significantly higher $(\mathrm{p}<0.05)$ as compared to $\mathrm{EG}, \mathrm{RJ}+\mathrm{EG}$, and $E G+R J$ groups $(p<0.05)$. All significant differences in renal GSH levels were also paralleled by differences in erythrocyte GSH levels.

Erythrocyte and kidney tissue CAT levels: According to erythrocyte CAT results presented in Table 3, while there were no significant differences between control and $\mathrm{RJ}$ group in terms of CAT ( $>0.05$ ), there was a significant difference between control and other groups $(\mathrm{p}<0.05)$. CAT in EG group was significantly $(\mathrm{p}<0.05)$ lower as compared to control, RJ and EG + RJ groups. Also, CAT in $\mathrm{RJ}+\mathrm{EG}$ and $\mathrm{EG}+\mathrm{RJ}$ groups were significantly reduced as compared to control $(\mathrm{p}<0.05)$.

According to renal CAT data shown in Table 3, there was a significant difference between CAT values in control and in EG and RJ groups $(p<0.05)$. Also CAT levels in $\mathrm{RJ}, \mathrm{RJ}+\mathrm{EG}$ and $\mathrm{EG}+\mathrm{RJ}$ groups were significantly higher as compared to that in EG group $(\mathrm{p}<0.05)$. 


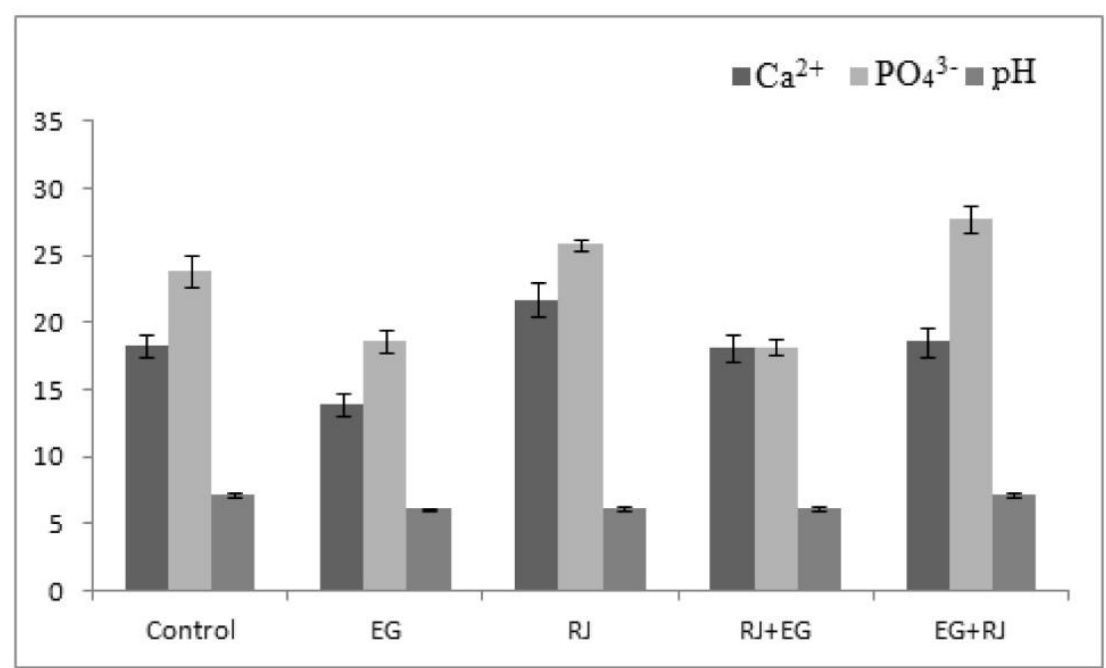

Figure 1. Urine $\mathrm{Ca}^{2+}, \mathrm{PO}_{4}{ }^{3-}$ concentration and urine $\mathrm{pH}$.

Şekil 1. İdrar $\mathrm{Ca}^{2+}, \mathrm{PO}_{4}{ }^{3-}$ konsantrasyonları ile idrar $\mathrm{pH}$.

Plasma and kidney tissue TAS levels: According to plasma TAS levels shown in Table 3, statistically significant differences were noted between all groups $(p<0.05)$. Renal TAS values showed a significantly lower TAS in EG group than in other groups $(p<0.05)$. There were no significant differences between control and RJ groups ( $p>0.05)$. TAS in RJ group was significantly higher as compared to EG, RJ + EG, and EG + RJ groups (p>0.05).

Urinary $\mathrm{Ca}^{2+}, \mathrm{PO}_{4}{ }^{3-}$ and urine $\mathrm{pH}$ : As shown in Figure 1, control rats did not differ significantly from RJ $+\mathrm{EG}$ and $\mathrm{EG}+\mathrm{RJ}$ groups in terms of $\mathrm{Ca}^{2+}$ concentrations, while $\mathrm{Ca}^{2+}$ was significantly higher in $\mathrm{RJ}$ group than in other groups $(\mathrm{p}<0.05)$. On the other hand, $\mathrm{Ca}^{2+}$ in EG group was significantly lower compared to other groups $(\mathrm{p}<0.05)$.

As shown in Figure 1, there was a significant difference between control and other groups with regard to $\mathrm{PO}_{4}{ }^{3-}$ concentrations. $\mathrm{PO}_{4}{ }^{3-}$ in $\mathrm{EG}$ and $\mathrm{RJ}+\mathrm{EG}$ groups was significantly lower than in other groups $(\mathrm{p}<0.05)$. $\mathrm{PO}_{4}{ }^{3-}$ concentration in $\mathrm{EG}+\mathrm{RJ}$ group was significantly higher as compared to other groups $(\mathrm{p}<0.05)$.

With regard to $\mathrm{pH}$ values, no significant differences between control and EG + RJ groups and between EG, RJ and $\mathrm{RJ}+\mathrm{EG}$ groups were observed. Accordingly, $\mathrm{pH}$ in control and EG + RJ groups were significantly higher than in other groups $(\mathrm{p}<0.05)$.

\section{Discussion and Conclusion}

Urolithiasis is one of the most common conditions of the urinary tract after urinary system infections and prostate disorders. Although etiology of urolithiasis is not clearly known, some risk factors that may facilitate formation of urinary tract stones have been defined. These particularly include genetic factors, ethnicity, age, gender, geographical location, nutrition habits, and smoking. Due to their crystalline structures, urinary stones are associated with initial tubular epithelial injury and even epithelial injury via a number of mechanisms. Tubular injury results from urolithiasis and nephrocalcinosis. At later stages, even urinary dysfunction may ensue. Ethylene glycol is a commonly utilized agent in animal experimentation to induce nephropathy. Ethylene glycol administration may lead to intrarenal accumulation of $\mathrm{CaOx}$ and acute renal injury (8).

Creatinine is a component produced in muscles by non-enzymatic changes of creatine and phosphocreatine. Urea plays key roles in the metabolism of nitrogencontaining compounds $(18,25)$. In this study, EG group CREA and BUN levels were higher than control group. EG group had a decrease in CREA and BUN levels compared to RJ+EG group. These values indicate kidney failure and therefore nephropathy in EG group.

MDA is the end-product of lipid peroxidation of unsaturated fats with at least three double bonds. Although MDA is not a quantitative or specific marker of fatty acid oxidation, it is considered to be the single most important indicator of membrane lipid peroxidation. This is due to the fact that MDA levels have a very good correlation with the degree of lipid peroxidation (13). Therefore, MDA is represented as an important oxidative stress marker which is able to cause direct injury on membrane structure, or indirect injury on other cellular components via the production of reactive aldehydes. Recent studies have proven the presence of oxidative stress in kidneys of patients with urolithiasis. For instance, Huang et al. (20) showed a remarkably high urinary excretion of MDA, a marker of oxidative stress, in individuals with renal calcium oxalate stones. Effects of oxidative stress and antioxidant effects of RJ were examined by El-Nekeety et al. (12) in a study where oxidative stress was induced by fumonisin in rats. A significant increase in MDA was found in rats receiving fumonisin, while a reduction was observed in rats receiving royal jelly. In another rat study, 
oxidative stress induction potential of carbon tetrachloride $\left(\mathrm{CCl}_{4}\right)$ and oxidative scavenger activity of royal jelly were examined, with increased MDA in rats that received $\mathrm{CCl}_{4}$ (9). MDA levels in our study are consistent with the above-mentioned findings. Results suggest that an increase in MDA occurs due to renal injury induced by ethylene glycol. In all groups that received royal jelly, detection of lower MDA levels as compared to EG group suggest an oxidative scavenger activity.

NO, which can be simultaneously synthetized by different cell types, is a fat-soluble molecule that can readily pass through biological membranes. Despite being a radical with low reactivity, NO promptly reacts with metal-containing centers and radicals. Its reaction with lipid radicals renders some antioxidant properties to NO. Peroxynitrite, which is formed by its reaction with superoxide, has hydroxyl radical-like activities and results in initiation of radical-involving reactions. In contrast with oxygen radicals, there are no specific enzymes responsible for clearance of nitric oxide. Nitric oxide is an important biochemical marker for oxidative stress (30).

In a study a modulating effect on oxidative stress and tissue injury was observed in rats exposed to gamma radiation. In that study, a significant reduction in NO was found in rats which only received royal jelly, while the group that received royal jelly after exposure to gamma rays had lower NO in comparison to NO in rats which only received gamma rays (4). In our study, in the group where urolithiasis was induced through ethylene glycol exposure in plasma, there was a resultant oxidative stress. A significant reduction in royal jelly group compared to EG group may be considered as an indicator of antioxidant efficacy.

In terms of TOS levels, i.e. total antioxidant status or total oxidant levels, a clear presence of oxidative stress due to renal injury induced by ethylene glycol can be observed in plasma and kidney. A modulating effect of royal jelly on oxidative stress can be inferred from the results observed in $\mathrm{RJ}, \mathrm{EG}+\mathrm{RJ}$, and $\mathrm{RJ}+\mathrm{EG}$ groups. In renal tissues, TOS in renal jelly group was lower than both control, EG + RJ and RJ + EG groups.

OSI was significantly higher in Group II, (i.e. in plasma and kidney samples in the ethylene glycol induced renal injury group) as compared to controls. This indicates that OSI is increased in plasma and kidney. Again, plasma OSI levels suggest that ethylene glycol induced oxidative stress in plasma in all groups, and while royal jelly was able to minimize oxidative stress, this was slightly lower as compared to controls. Renal OSI estimates showed an oxidative effect for ethylene glycol, and royal jelly appeared to have most prominent protective and therapeutic effects on this tissue. Absence of a significant difference between prophylaxis and therapy groups and absence of a difference in OSI between royal jelly and control lend support to this assumption.
GSH is a tripeptide consisting of glutamic acid, cysteine and glycine amino-acids. It may either show direct antioxidant effects or supportive effects through catalysis of the reduction of hydroperoxides with GSH-Px (36). It represents an important biochemical antioxidant marker. Huang et al. (20) observed lower levels of protein, thiol and vitamin $\mathrm{E}$ levels in urolithiasis patients, in addition to lowered GSH and GSH-Px activity. Cemek et al. (9), in their study examining the antioxidant scavenging activity of royal jelly against $\mathrm{CCl}_{4}$, found increased GSH in royal jelly group. El-Nekeety et al. (12) measured effects of fumonisin and royal jelly in rats and observed a decrease in GSH in fumonisin group, while significant increases in GSH were found in royal jelly and royal jelly + fumonisin groups. In our study, lower levels of GSH in EG, EG + RJ and RJ + EG groups than in royal jelly group suggest a strong oxidative stress induced by ethylene glycol and an augmented oxidative stress by renal injury. GSH in royal jelly group did not differ significantly from control, which suggest that adequate GSH, which is a substrate, was provided for use by the activity of GSH converting enzymes, i.e. GSH-Px and GSH-Rd. On the other hand, absence of a difference in GSH between EG and $E G+R J$ and RJ + EG suggests that effects of royal jelly augmenting antioxidant capacity of GSH were probably suppressed by ethylene glycol.

CAT, an endogenous enzymatic antioxidant, is mostly found in peroxisomes which also include multiple enzymes that are able to produce hydrogen peroxide. The highest levels of CAT activity are found in erythrocytes. It is also found in mucus membranes and kidney. It is a specific enzyme for $\mathrm{H}_{2} \mathrm{O}_{2}$, catalyzing the conversion of hydrogen peroxide into water and oxygen without an effect on other organic peroxides $(33,36)$. Eraslan et al. (13) studied the effects of another bee product, propolis, on rats treated with sodium fluoride, and found an increased catalase activity in rats receiving short or long term treatment with sodium fluoride and propolis. An article on hyperoxaluria and antioxidants, explained the reduction in crystal formation on the basis of an increased activity of enzymes such as CAT, GSH-Px, and SOD, strengthening antioxidant defense system (23).

Examination of CAT levels in our study clearly indicates a decreased antioxidant level in rats in which urolithiasis was induced. Contribution of royal jelly to antioxidant defenses can be inferred from CAT levels, which increased significantly in groups receiving royal jelly. Erythrocyte CAT level in RJ group was higher as compared to $\mathrm{EG}+\mathrm{RJ}$ and $\mathrm{RJ}+\mathrm{EG}$ groups, while there were no differences in CAT levels in kidney tissue in these three groups.

In a study by Cihan et al. (11) looking at the effect of royal jelly on oxidative stress induced by radiotherapy in rats, they observed a regulatory and positive effect of royal jelly on total antioxidant status. El-Nekeety et al. (12) 
inducing oxidative stress in rats by fuminosin examined antioxidant effects of royal jelly. These authors observed a significant improvement in antioxidant level of the group that received both fumonisin and royal jelly. In our study, there was a significant decrease in TAS in ethylene glycol group as compared to royal jelly and control groups, showing that renal injury resulted in reduction in antioxidant capacity. Plasma samples in royal jelly groups had lower antioxidant levels as compared to controls, while there were no differences between royal jelly and control groups in renal samples. However, when EG group is considered, a significant improvement in antioxidant capacity of royal jelly groups can be noted. As compared to EG group, rats in EG + RJ and RJ + EG groups had significant improvement in their TAS levels. This suggests an augmenting effect of royal jelly on antioxidant capacity. While there was a more marked improvement in the plasma samples in treatment groups as compared to prophylaxis group, there were no significant differences between treatment and prophylaxis groups in terms of TAS capacity.

Accumulation of crystals (calcium phosphate) at the tip of papilla associated with stone formation was originally described by Randall in 1937, leading to denomination of Randall's plaques. Randall suggested that calcium phosphate crystals accumulate between cells, resulting in formation of heterogeneous nucleisation centers for calcium oxalate excreted into collecting system. Ethylene glycol is rapidly absorbed and reaches liver through portal circulation following administration. It is converted to glycolaldehyde with $\mathrm{ADH}$ and other hepatic enzymes. Glycolaldehyde is converted into glycol alcohol, which is responsible for acidosis in ethylene glycol toxication. Glycol alcohol is then converted into glycolate, glycolic acid, and oxalic acid in that specified order. In the presence of $\mathrm{Ca}^{2+}$ and oxalic acid, calcium oxalate stones are formed (10). In a number of studies examining effects of several substances on urolithiasis induced by ethylene glycol, urinary $\mathrm{Ca}^{2+}$ levels were also measured. These studies reported a significantly increased urinary $\mathrm{Ca}^{2+}$ concentration in ethylene glycol groups as compared to control $(2,35)$. On the other hand, others have reported varying concentrations of urinary $\mathrm{Ca}^{2+}$ in urolithiasis induced by ethylene glycol. In a study by Hosseinzadeh et al. (19) juicy extract of Pinus Eldarica Medw. Fruit was examined in terms of its antiurolithiasis effect; also urinary $\mathrm{Ca}^{2+}$ concentrations were measured. The group that received ethylene glycol had higher $\mathrm{Ca}^{2+}$ concentrations as compared to control however, the difference was not significant. Atmani et al. (3) studied the Herniaria hirsuta $L$. plant and measured urinary $\mathrm{Ca}^{2+}$ concentrations at $0,1,2$, and $3^{\text {rd }}$ weeks of the study. The results were similar in ethylene glycol group at 0,1 and $3^{\text {rd }}$ weeks, while a lower urinary $\mathrm{Ca}^{2+}$ was found as compared to control. In our study also $\mathrm{Ca}^{2+}$ concentrations were significantly lower in ethylene glycol group than in controls. Also there were no significant differences in urinary $\mathrm{Ca}^{2+}$ levels between controls, prophylaxis and therapy groups. Only the rats in royal jelly group had significantly higher urinary $\mathrm{Ca}^{2+}$ levels than other groups. In many studies with duration of 4 weeks or 30 days, renal injury occurs through exposure to ethylene glycol, while longer (4-8 weeks) EG-Drinking model studies are required for the occurrence of urolithiasis. In this regard EG-drinking model studies are warranted (28). In this study, it may be more appropriate to mention a renal injury effect rather than urolithiasis.

Rat urinary $\mathrm{pH}$ is normally between 7 and 8 . In our study urinary $\mathrm{pH}$ values in control and treatment groups were within normal ranges. A significant reduction in $\mathrm{pH}$ was noted in ethylene glycol, royal jelly and prophylaxis groups. Royal jelly is an acidic gel with a $\mathrm{pH}$ between 3.6 and 4.2. Dietary intake of royal jelly throughout the study in both royal jelly and prophylaxis groups may be responsible for the reduction in urinary $\mathrm{pH}$.

Ethylene glycol results in cellular injury through leading increased oxalate concentrations in renal tubular cells and through the formation of $\mathrm{CaOx}$ crystals. In turn, renal tubular epithelial damage results in ROS formation. Resultant oxidative stress induces tissue injury and inflammation. Many studies have shown that renal tubular injury is associated with the production of free oxygen radicals. Until now numerous phytomedical or products of animal-origin have been tested with regard to their protective effects on renal injury/urolithiasis. In the present study, royal jelly, a substance with documented antioxidative properties, has been examined. It was found that royal jelly has favorable influence on renal injury and lipid peroxidation induced by ethylene glycol. A comparison of its preventive effects with therapeutic effects on renal injury suggests that it may exert more pronounced effects on injured tissues. Despite this observation, further metabolic studies examining effects of royal jelly on ethylene glycol are warranted.

Conflict of interest statement: We declare that, this study was financially supported by Scientific Research Projects Committee (project number: 13.FENBIL.30), Afyon Kocatepe University, Afyonkarahisar, Turkey.

\section{References}

1. Aebi H (1974): Methods of Enzymatic Analysis, Catalase. Academic Press, New York, NY, USA.

2. Ashok P, Koti CB, Vishwanathswamy AHM (2010): Antiurolithiatic and antioxidant activity of Mimusops elengi on ethylene glycol-induced urolithiasis in rats. Indian $\mathbf{J}$ Pharmacol, 42, 380-383.

3. Atmani F, Slimani Y, Mimouni M, et al. (2004): Prophylaxis of calcium oxalate stones by Herniaria hirsuta on experimentally induced nephrolithiasis in rats. BJU Int, 92, 137-140. 
4. Azab KS, Bashandy M, Salem M, et al. (2011): Royal jelly modulates oxidative stress and tissue injury in gamma irradiated male Wister Albino rats. N Am J Med Sci, 3, 268276.

5. Beutler E, Dubon O, Kelly BM (1963): Improved method for the determination of blood glutathione. J Lab Clin Med, 61, 882-888.

6. Bradford MM (1976): A rapid and sensitive method for the quantitation of microgram quantities of protein utilizing the principle of protein-dye binding. Anal Biochem, 72, 248-254.

7. Brouwers EMW, Ebert R, Beetsma J (1987): Behavioural and physiological aspects of nurse bees in relation to the composition of larval food during caste differentiation in the honeybee. J Apic Res, 26, 11-23.

8. Caudarella R, Vescini F (2009): Urinary citrate and renal stone disease: The preventive role of alkali citrate treatment. Arch Ital Urol Androl, 81,182-187.

9. Cemek M, Aymelek F, Büyükokuroğlu ME, et al. (2010): Protective potential of Royal Jelly against carbon tetrachloride induced-toxicity and changes in the serum sialic acid levels. Food Chem Toxicol, 48, 2827-2832.

10. Chen YH, Liu HP, Chen HY, et al. (2011): Ethylene glycol induces calcium oxalate crystal deposition in Malpighian tubules: A Drosophila model for nephrolithiasis/ urolithiasis. Kidney Int, 80, 369-377.

11. Cihan YB, Öztürk A, Gökalp SS (2013): Protective role of royal jelly against radiation- induced oxidative stress in rats. Int J Hematol Oncol, 23, 79-87.

12. El-Nekeety AA, El-Kholy W, Abbas NF, et al. (2007): Efficacy of royal jelly against the oxidative stress of fumonisin in rats. Toxicon, 50, 256-269.

13. Eraslan G, Kanbur M, Silici S (2007): Evaluation of propolis effects on some biochemical parameters in rats treated with sodium fluoride. Pest Biochem Physiol, 88, 273-283.

14. Erel Ö (2004): A novel automated method to measure total antioxidant response against potent free radical reactions. Clin Biochem, 37, 112-119.

15. Erel Ö (2005): A new automated colorimetric method for measuring total oxidant status. Clin Biochem, 38, 11031111.

16. Favus MJ (1989): Familial forms of hypercalciuria. J Urol, 141, 719-722.

17. Gupta RK, Patel AK, Shah N, et al. (2014): Oxidative stress and antioxidants in disease and cancer: A review. Asian Pac J Cancer Prev, 15, 4405-4409.

18. Hamilton RW, Gardner LB, Penn AS, et al. (1972): Acute tubular necrosis caused by exercise-induced myoglobinuria. Ann Intern Med, 77, 77-82.

19. Hosseinzadeh H, Khooei AR, Khashayarmanesh Z, et al. (2010): Antiurolithiatic activity of Pinus Eldarica Medw. Fruits aqueous extract in rats. Urol J, 7, 233-237.

20. Huang HS, Ma MC, Chen CF, et al. (2003): Lipid peroxidation and its correlations with urinary levels of oxalate, citric acid, and osteopontin in patients with renal calcium oxalate stones. Urology, 62, 1123-1128.

21. Iannuzzi J (1990): Royal Jelly: Mystery food. Am Bee J, 130, 587-589.
22. Jain SK, McVie R, Duett J, et al. (1989): Erythrocyte membrane lipid peroxidation and glycolylated hemoglobin in diabetes. Diabetes, 38, 1539-1543.

23. Khan S (2005): Hyperoxaluria-induced oxidative stress and antioxidants for renal protection. Urol Res, 33, 349357.

24. Kubo T, Sasaki M, Nakamura J, et al. (1996): Change in the expression of hypopharyngeal gland proteins of the worker honeybees (Apis mellifera L.) with age and/or role. J Biochem, 119, 291-295.

25. Kurzer F, Senderson PM (1956): Urea in the history of organic chemistry. J Chem Educ, 33, 452-459.

26. Lercker G, Capella P, Conte LS, et al. (1981): Components of Royal Jelly: Identification of the organic acids. Lipids, 16, 912-919.

27. Lerolle N, Lantz B, Paillard F, et al. (2002): Risk factors for nephrolithiasis in patients with familial idiopathic hypercalciuria. Am J Med, 113, 99-103.

28. McMartin K (2009): Are calcium oxalate crystals involved in the mechanism of acute renal failure in ethylene glycol poisoning? Clin Toxicol, 47, 859-869.

29. Miranda KM, Espey MG, Wink DA (2001): A rapid, simple spectrophotometric method for simultaneous detection of nitrate and nitrite. Nitric Oxide, 5, 62-71.

30. Neroev VV, Arkhipova MM (2003): Retinal ischemia and nitric oxide. Vestn Ross Akad Med Nauk, 5, 37-40.

31. Ohkawa H, Ohishi N, Yagi K (1979): Assay for lipid peroxides in animals and tissues by thiobarbituric acid reaction. Anal Biochem, 95, 351-358.

32. Pavel CI, Mărghitaş LA, Bobiş O, et al. (2011): Biological activities of royal jelly. Scientific Papers. J Anim Sci Biotechnol, 44, 108-118.

33. Rubiolo JA, Mithieux G, Vega FV (2008): Resveratrol protects primary rat hepatocytes against oxidative stress damage: Activation of the Nrf2 transcription factor and augmented activities of antioxidant enzymes. Eur $\mathbf{J}$ Pharmacol, 591, 66-72.

34. Thomas MJ (2000): The role of free radicals and antioxidants. Nutrition, 16, 716-718.

35. Yasui T, Fujita K, Sato M, et al. (1999): The effect of takusha, a kampo medicine, on renal stone formation and osteopontin expression in a rat urolithiasis model. Urol Res, 27, 194-199.

36. Young IS, Woodside JW (2001): Antioxidants in health and disease. J Clin Pathol, 54, 176-186.

37. Zheng HQ, Hu FL, Dietemann V (2011): Changes in composition of royal jelly harvested at different times: Consequences for quality standards. Apidologie, 42, 39-47.

Geliş tarihi: 27.10.2015 / Kabul tarihi : 15.12.2016

Address for correspondence:

Assoc. Prof. Dr. Laçine AKSOY

Afyon Kocatepe Universitesi,

Fen Edebiyat Fakültesi, Kimya Bölümü,

03200, Afyonkarahisar, Türkiye

e-mail:lacinetur@aku.edu.tr 